\title{
Research on Hierarchical Modular Training Mechanism of Innovative Engineering Training
}

\author{
Xiumei Luan* \\ Engineering Training Center \\ Qilu University of Technology \\ Jinan, China \\ Lxm@qlu.edu.cn
}

\begin{abstract}
Due to the drawbacks of the present engineering training teaching system, this paper explores hierarchical and modularity engineering training teaching system. This system includes three levels: Practice teaching, Technology competition, Innovation and entrepreneurship. Each level condensed into multiple training modules, focusing on the project. The teaching system has achieved good teaching results.
\end{abstract}

Keywords-engineering training; hierarchical; practice teaching; training mechanism

\section{INTRODUCTION}

After more than 10 years of development, the University Engineering Training Center in our country has undergone qualitative changes in the construction of hardware facilities and environment. The current situation is that most engineering training center in our colleges and universities are set up based on the original metalworking practice and some also contain a the contents of electronic technology practice, which is a common problem ,such as obsolete teaching content, single and no systematic teaching system. It needs a step in the hardware facilities and the level of training while connotation construction is lagging behind. This situation cannot meet the requirements of students' comprehensive quality and innovative ability. It needs further reform and development [1, 2].

This paper explores the engineering training establishment hierarchical modular teaching system. Namely, "Practice teaching, Technology competition, Innovation and entrepreneurship" .each level condensed into multiple training modules, focusing on the project.

\section{Present Foreign AND DOMESTIC RESEARCH}

Because of the new era of engineering practice in the field of innovation requirements, in other countries, developed earlier amendment introduced certification standards related to engineering education. For instance, the Accreditation Board for Engineering and Technology in 1998 the United States enacted the EC2000 (Engineering Criteria 2000), different from the previous standard that it pay more attention to students' practical ability, the spirit of collaboration and the level of engineering ethics and other aspects of engineering .The standard clearly have the knowledge, ability and literacy, for engineering and technical education in the United States and the world had a profound impact.
Subsequently, FEANI (The European Federation of National Engineering Association), namely the European Federation of Engineering Association started in 2004 the certified engineers plan, vigorously promote innovation and engineering and technical education, combined with the European members of the body of the hardware, software and technology, develop new excellent engineer needs of the times; Japan launched in 2002 JABEE (Japanese Accreditation Board of Engineering Education) certification program for its own engineering and technical personnel training was refined to enhance the goal of innovative personnel training, construction conditions and investment plan, strive world innovative engineering and technical personnel of high ground. Korea implemented in 2008 ABEEK (Accreditation Board of Engineering Education), attention to innovation and quality engineering education, engineering and technical personnel in the era of globalization presents an innovative, high-quality talent strategic plan[3].

In China, the Ministry of Education has proposed a program in 2010: remarkable engineer education training program-the program of work (2011-2012).Excellence program's goal is: for the industry, for the world and the future, train a large number of innovation capability, adapt to economic and social development needs of various types of high-quality engineering and technical personnel, for the construction of an innovative country to achieve industrialization and modernization lay a solid human resources advantages, enhance our core competitiveness and overall national strength.

In May 2015, the State Council issued "Opinions on Deepening the Reform of Higher Education in innovation and entrepreneurship" .Fully deployment the work about deepening the reform of higher education innovation and entrepreneurship. It escort for surging tide of innovation and entrepreneurship, once again called the innovation and entrepreneurship. To deepen the reform of colleges and universities innovation and entrepreneurship education as a breakthrough to promote comprehensive reform of higher education, innovation and entrepreneurship education universal. So that innovation and entrepreneurship become school administrators, teachers teaching, students study the rational cognition and conscious action. Universities Engineering Training Center as a platform for innovation and entrepreneurship becomes more and more attention to the university, which is focusing on content development [4-6]. Shandong University Engineering Training 
Center established a science and technology research and development-oriented competition and innovation training platform. Dalian University Engineering Training Center as a national experimental teaching demonstration center attaches particular importance to college students to carry out practical activities scientific and technological innovation and it developed a more comprehensive policy and system. With a national experimental teaching demonstration center Beijing University of Aeronautics and Astronautics Engineering Training Center after a long exploration, and summarized in the national universities lead in establishing a "multi-type, hierarchical, modular" teaching system .The education system reflects the Engineering Training Center, "based on categories of professional platform for the engineering practice, the convergence of Teaching, and the ability to focus on quality, innovative teaching model" teaching philosophy. In recent years, our school leadership attaches particular importance to engineering training center; the school began the integration of various types of software and hardware resources for rapid development of engineering training center foundation. Through research, we analyzed engineering colleges and universities training practice teaching system and established a hierarchical modular engineering training practice teaching system.

From 2014, our school began to speed up the development of the engineering training center, and increase the hardware resources. At the same time, Engineering training complete management mechanism and introduce professional talents. In order to strengthen the construction of the central institutions and teams, the personnel training work has been carried out, and retired experts have been employed to provide technical advice and guidance. We had organized and visited University of Jinan, Shandong University, Shandong Jianzhu University, Shandong Jiaotong University and some fraternal engineering training centers in Qingdao. In recent years, Engineering Center increased teaching research projects and skills training project construction. The overall construction is in full swing.

\section{EngineERING Training HierarchicAl ModUlaR PRACTICE TEACHING SYSTEM}

To cultivate innovative talents, the practice teaching system of engineering training in Colleges and universities is explored[7-9].This article explores and established a hierarchical modular innovative new training mechanism, shown in Figure 1. The new training mechanism includes the practice of teaching, science and technology competition, innovation and entrepreneurship. And the project as a center and condensed into a plurality of training modules. Our main goal is to encourage colleges participate in organization of various types of high-level innovative skills at all levels of competition, exercise and enhance innovative ability and level of our students.it not only benefit the students, but also get glory for the school

\section{A. Practical Teaching}

1) Continue to do traditional engineering training projects

a) Casting, welding, turning, milling, planing, CNC machining, mechanical assembly, fitter

b) Computer disassembling

c) Ceramic molding technology

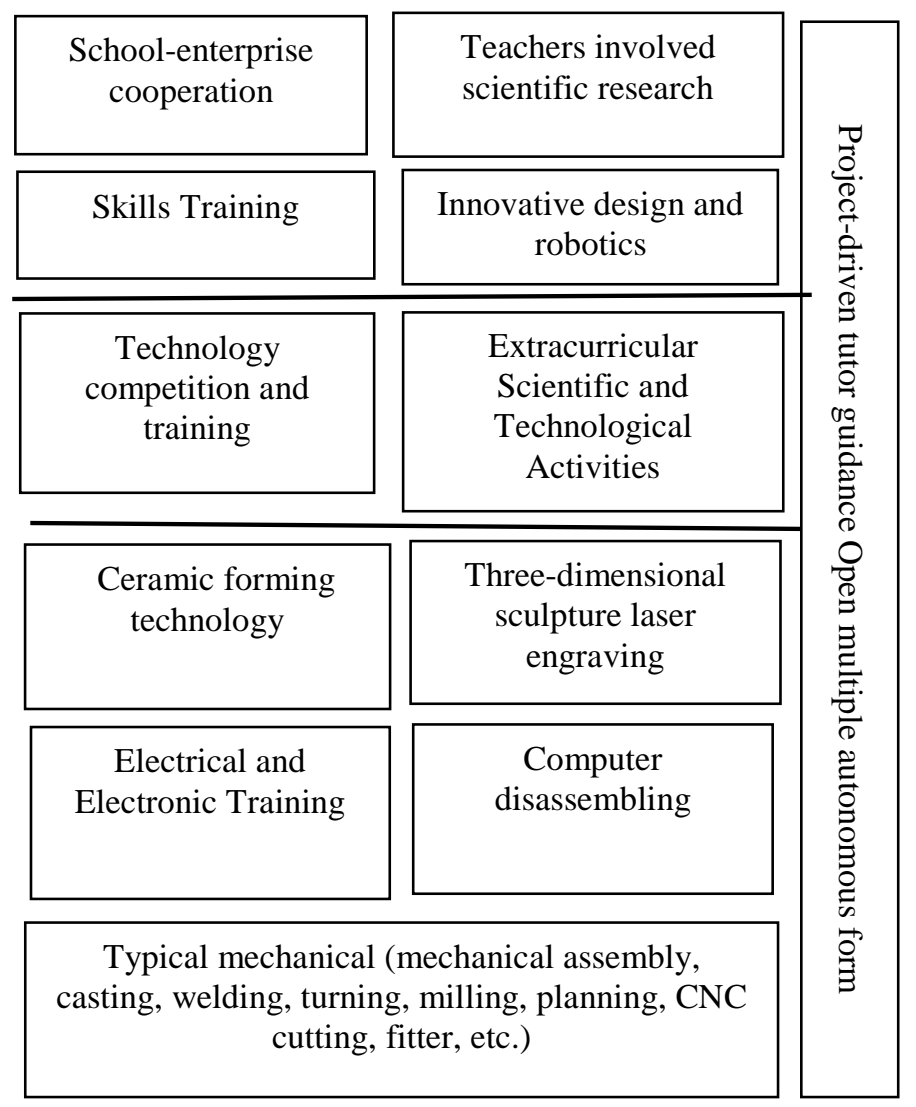

Fig. 1. Project hierarchical modular training Practical Teaching System

\section{2) Expand Training Project}

To further explore the training program and enhance students' ability of engineering training, engineering training center create conditions actively to expand the training program in content and quantity. In 2015, our school carries on a new line cutting, CNC milling, three-dimensional sculpture, laser engraving four training projects; greatly improved my school's engineering training in scope and level.

\section{3) Continue the integration of resources}

Promoting the training center in integration of resources and setting up training programs for electric and electronic training.

\section{B. Technology Competition}

- Collaborative school departments do further integration of various scientific and technological competition, making use of engineering training platform for innovation and doing well in training of students' innovative and carrying out extracurricular 
science and technology activities, such as science and technology interest groups, various social and technical services as a second class for the professional students of all ages to carry. It could cultivate student science and technology awareness. Promote the formation of professional teacher guidance, senior students to promote low-grade students to carry out scientific and technological activities of the fine tradition.

- Our school organized and carried out a number of engineering training skills competition, including Turner, fitter, carving, welding, casting, machining, The competition ranked the 123 prize with 36.And greatly enhance the students' engineering skills and innovative ability. At the same time, this event reserves the resources for participating in higher competition, and improves the effect and influence of engineering training. Generally speaking, the competition was well received.

- Organize Students to participate in the national team competition actively (such as mechanical and electrical products contest, robot contest, Electronic Design Contest, etc.) to improve the level of innovation my college students.

- In 2017, for the first time to participate in the "Tenth International Water robot contest", our team's outstanding results, won 1 First Prize, Second Prize 1, Third Prize 2.

\section{Innovation and entrepreneurship}

\section{1) Innovation and Entrepreneurship}

Do a good job about training students creative work, construction creating customer base, build record passenger platform, organizations create customer groups, organize students to participate in the domestic competition actively, improve the students' level of innovation.

In order to cooperate with the work of the Institute of entrepreneurship, we had actively engaged in Entrepreneurship and employment activities. Our school has joined the International Federation of creative customers, the alliance of smart industries, and the Shandong provincial alliance to create customers, and so on.

Currently our school has been used as the first engineering training center governing units joined the "China Shenzhen International Year off Union students", other relevant preparation and coordination of work is actively underway.

Our school has opened up Mechanical passenger space, Electronic guest space, Comprehensive production, Qilu workshop (Stone forming technology,, Wood forming technology, Ceramic art modeling, Ceramic material forming technology) and other innovative practice training projects.

In order to improve the level of innovation and manufacture of students in our university, at the end of 2016, a training platform for robot skills was built in the engineering training center of our university. The platform is divided into 4 modules: Aerial Robot, land robot, underwater robot and industrial robot.
It greatly enriches and promotes the content and level of innovative practice training in our university.

\section{2) Skills Training Project}

In order to improve the quality of employment of college students, Cooperate with the school to better cultivate directly serve the local economic and social development of applied talents, engineering training center after work actively to strive for and won the Shandong Provincial Human Resources and Social Department and other agencies of opportunities for cooperation, carried out for school related technical vocational qualification certificate training. The training programs can be up to 17, qualification certificate issued by Shandong Province and Social Council Chamber or the relevant functional departments issued

\section{CONCLUSION}

Engineering Training hierarchical modular Students Practice Teaching System Engineering Practice and Training will be divided into "practice teaching, science and technology competition, innovation and entrepreneurship," The project as a center and condensed into a plurality of training modules into four years of college the teaching process. The protection of "engineering training four continuous line to meet different professions, different levels of students to drive flexible practical training course content needs teaching methods.it could help students cultivate practicing ability, innovation and engineering projects .It also help improve the overall quality of the comprehensive.We will continue to actively explore and strive to improve engineering training hierarchical modular practice teaching system.

\section{ACKNOWLEDGEMENT}

The thesis is supported by the teaching reform research project of Shandong higher education institution (No.Z2016M018).

\section{REFERENCES}

[1] Pengju M, Liang W, Dianming H.Establishing a MuIt-Disciplinary Engineering Training Platform of Modern Manufacturing, Electronics and Control Science[J]. Higher engineering education research:127-130. (In Chinese)

[2] Daju Z, Zhaoqin Y. Cultivation of Innovative Thinking in Mechanic Skill Training[J]. RESEARCH AND EXPLORATION IN LABORATORY,2012(8):371-373. (In Chinese)

[3] Qingyun D,ZHONG Runyang Z,Meilin W,et al. Innovation and Practice of Distinctive Engineering Training under Informatics Environment-Taking GDUT as an Example[J]. Science and Technology Management Research,2014(4):80-85. (In Chinese)

[4] Hongliang Y, Changchun S,Yuanying D ,et al. Discussion on Construction of Innovative Center of Engineering Training and Training Model of Innovative Students[J].China Modern Educational Equipment,2015(1):30-32. (In Chinese)

[5] Bolin H, Guangyao X, Xianfeng X, et al. The Practice and Notions of Building Demonstration Engineering Training Center[C]. ETT2010:332-335. (In Chinese)

[6] Xiaohong W, Xiaoming Z. Research and practice of modern project training educational mode[J].Experimental Technology and Management,2009(6):118-123. (In Chinese)

[7] Chunrong W, Baoren T. Relying on superior resources of engineering training center to build innovative platform for college students[J]. 
Experimental Technology and Management, 2014(11):147-149. (In Chinese)

[8] Hua L, Bo W, Enjiang X,et al. Construction and Practice on Multilevel and Open Engineering Training Teaching System[J]. Experiment Science and Technology, 2012(1):134-137. (In Chinese)
[9] Zhanfeng G,Janchao Z,Wenjiang W, et al. Construction of innovative engineering training system based on Engineering Training Center[J]. Education Teaching Forum, 2013(12):26-28. (In Chinese) 